\title{
Dark-age cities discovered
}

\section{Richard Hodges}

RECENT archaeological finds in several areas of Europe demonstrate the value of excavation rather than relying on contemporary written records for a complete understanding of mediaeval societies. Arguably the most important recent discovery' that provides a piece of the enigmatic jigsaw of our picture of seventhcentury societies is that of Quentovic, a town near Montreuil in northern France.

The history of early mediaeval trade and commerce around the North Sea basin has been gradually pieced together from an unexpected series of discoveries. The great port of Dorestad, located in the Rhine estruary, was found by starving peasants rooting around the early mediaeval bone-pits (as they described them) and boiling up their contents. Subsequent excavations revealed that this town covered up to $100 \mathrm{ha}$, and served the Rhineland and Low countries much as modern Rotterdam does today.

Hamwic, Anglo-Saxon Southampton, was identified in much the same way when local people in victorian times plundered the rubbish pits for their well-preserved bone and discovered silver coins at the same time. Major excavations since then have confirmed that in Wessex, as on the European continent, great trading centres were a feature of this age while old Roman towns lay in ruins. Hamwic, it now appears, covered an area of about 45 ha of low-lying ground beside the river Itchen. On the site of Ipswich, in the kingdom of the East Angles, there was another port of similar dimensions. Although unrecorded by the chroniclers of the age, Ipswich was undeniably a major centre, as excavations ${ }^{2}$ over the past 10 years have shown.

Written sources describe other likely emporia, but until recently these have eluded archaeologists. Lundenwic (AngloSaxon London), according to the Venerable Bede, was a trading town of some importance by the late seventh century. Yet numerous excavations within the old Roman city indicate that the place was largely overgrown and abandoned. Recently, however, Martin Biddle and Alan Vince independently suggested ${ }^{3,4}$ that the Middle Saxon port lay not on the site of the Roman city, but in the Aldwych area west of the ruins. In 1986, excavations at Covent Garden, situated in this area, confirmed their hypothesis. Evidence of early mediaeval occupation, including buildings, pits and a great range of rubbish, worthy of a cosmopolitan rather than a rural community, was brought to light.
At York, virtually the same pattern has been discovered. Many excavations within the Roman and later Viking centre revealed little or nothing of the emporium described in writing by Alcuin, Charlemagne's Northumbrian minister. But excavations $^{5}$ at the Redfearns glass foundry site, outside the east walls of the Roman and mediaeval city, revealed the characteristically rich debris of the port that had for so long been elusive. The settlement appears to have been located at the confluence of the rivers Ouse and Foss, though it remains to be seen whether it matches the other English dark-age towns in size and complexity.
Low Countries and as far north as Denmark were based, whereas Quentovic seems to have been the base for traders covering northern and central France as well as southern England. Both ports were lynchpins in Charlemagne's ambitious economic strategy, becoming the focus of great wealth. Both inevitably attracted the attention of the Vikings, who repeatedly pillaged them ${ }^{6}$. Like Dorestad, Quentovic was deserted in the later ninth century, remaining a monument to a brief but influential phase in European urban history.

In 1984, a team from Manchester and Sheffield universities led by Dr David Hill began to search for this lost city in the Canche valley, east of Etaples. The Frankish sources offered some clues as to its whereabouts, but the time-consuming method of digging test pits turned out to be the only way to pinpoint its position. In 1985, the team identified it on low-lying ground in the commune of Vismarest at the head of the valley of the river Canche, immediately below mediaeval and modern Montreuil and 15 $\mathrm{km}$ from the English Channel. Debris from the town is packed with pottery, bone, glass and industrial debris, and the test pits indicate that the town covered about 70 ha.

The first publication" of some of these finds leaves no doubt that it is Quentovic that has been discovered. The pottery found confirms that the town had closer trading ties with the English than did Dorestad, for instance. It also shows that the port drew on a hinterland every bit as large as Dorestad, reaching southwards to the Paris basin and north as far as the Ardennes. The small investigations at Quentovic, like those in London and York, have to be treated with caution. Nevertheless, at Quentovic the occupation debris, left much as it was following Viking attacks in the 840 s, remains tantalizingly undisturbed beneath pastureland. Peeling back the turf to reveal these deposits will be no less as important for historians of the dark ages than the discovery of Tutenkhamun was for egyptologists. At Quentovic, and in contrast to the English towns, there has been little robbing and no subsequent occupation. Indeed, it seems to have eluded discovery until now because its rich haul of animal bones, buried in the damp layers of the Canche valley, never held any attraction for the peasants of the Pas de Calais.

\footnotetext{
. Coutts. C. \& Worthington, M. Medieval Ceramics 10,23-28 (1986).

. Hodges, R. Dark Age Economics (Duckworth, London, 1982).

3. Biddle, M. Archaeology 6. 23-27 (1984).

4. Vince, A. G. Current Archaeol. 310-312 (1984)

5. Kemp, R. Interim Bull. York Archaeol. Trust, 11, 8-16(1986).

6. Lebecq, S. Ann. ESC 2, 361-77 (1986).
}

north of the Alps in the seventh century.

Both places were a springboard for Frankish trade with the English and Danes: Dorestad was the centre in which traders operating in the Rhineland, the
Richard Hodges is in the Department of ArchSheffield S10 2TN, UK. aeology and Prehistory, University of Sheffield, 